\title{
First isolation in Argentina of a highly virulent Shiga toxin-producing Escherichia coli 0145:NM from a domestic cat
}

\author{
María Valeria Rumi ${ }^{1}$, Kinue Irino ${ }^{2}$, Natalia Deza ${ }^{3}$, Miguel J. Huguet ${ }^{4}$, Adriana B. Bentancor ${ }^{1}$ \\ ${ }^{1}$ Microbiología, Facultad de Ciencias Veterinarias, Universidad de Buenos Aires, Argentina \\ ${ }^{2}$ Instituto Adolfo Lutz, Sao Paulo, Brazil \\ ${ }^{3}$ Servicio de Fisiopatogenia, Instituto Nacional de Enfermedades Infecciosas, ANLIS "Dr Carlos G. Malbrán", \\ Argentina \\ ${ }^{4}$ Genética, Facultad de Ciencias Veterinarias, Universidad de Buenos Aires, Argentina
}

\begin{abstract}
Introduction: Hemolytic uremic syndrome (HUS) is distributed worldwide. In Argentina, more than 450 cases of HUS, mostly sporadic, are reported annually. The main serotype isolated is O157:H7, and among non-O157 STEC, O145:NM is the most frequent strain. We studied the relationship of companion animals living in contact with a child with sporadic HUS, as carriers of Shiga toxin-producing Escherichia coli (STEC) strains.

Methodology: Duplicate rectal swab samples were taken weekly from the household cat and dog at the home of a patient with HUS. Samples were plated on MacConkey and sorbitol MacConkey-CT agar. Confluent growth from each plate was screened for the presence of $s t x_{1}$, stx $x_{2}$ and $r f b_{\mathrm{O} 157}$ gene by PCR assays. Up to 300 individual colonies taken from positive plates at screening were retested by PCR.

Results: The strain from the cat belonged to the highly virulent serotype O145:NM. Although this strain differed antigenically from the strain isolated from a child with HUS living in the same house, both carried the $s t x_{2}$, eae and $e h x \mathrm{~A}$ virulence genes. The strain isolated from the dog belonged to the serotype O178:H19.

Conclusions: An asymptomatic household cat may harbour the high virulent STEC strain, such as O145:NM, the second most frequently STEC serotype associated with HUS in Argentina. Companion animals are probably exposed to the same sources as the humans. More studies are needed to establish dogs and cats as sources of infection in the epidemiological cycle of infections caused by STEC strains, and to develop effective control strategies for this pathogen.
\end{abstract}

Key words: STEC; HUS; cat; pet

J Infect Dev Ctries 2012; 6(4):358-363.

(Received 01 August 2011 - Accepted 03 November 2011)

Copyright (C) 2012 Rumi et al. This is an open-access article distributed under the Creative Commons Attribution License, which permits unrestricted use, distribution, and reproduction in any medium, provided the original work is properly cited

\section{Introduction}

Hemolytic uremic syndrome (HUS) is widely distributed around the world. In Argentina, more than 450 cases of HUS are reported annually, and in the last five years the notification rate has increased by $1.7 \%$ [1]. HUS is the main cause of acute renal failure and is responsible for $20 \%$ of the renal transplants among children in this country [2]. Humans frequently become infected with Shiga toxin-producing Escherichia coli (STEC) by the ingestion of contaminated food or water, person-toperson transmission, or direct contact with animals that represent a threat for STEC infection (e.g., farm animals, ruminants) $[3,4,5]$. Food has been identified worldwide as the source of infection in approximately half of the cases of HUS [6]. Despite that ruminants in general and cattle in particular have been implicated as the main STEC reservoirs [7], other animals can also maintain the strains in the environment $[8,9]$. A carrier rate of E. coli $\mathrm{O} 157: \mathrm{H} 7$ in companion animals was recently described by Kataoka et al. in Japan [10]. The aim of this study was to evaluate the relationship of household pets, a cat and a dog, living in contact with a child with HUS, as carriers of Shiga toxin-producing Escherichia coli (STEC) strains and their potential role in the epidemiological cycle of STEC infection.

\section{Methodology}

Ethical considerations

The pets were handled under the supervision of licensed veterinarians according to standards set by the Institutional Ethics Committee, Faculty of 
Veterinary Science, University of Buenos Aires, Argentina.

\section{Patient}

The patient was an 11-year-old boy with diagnosis of HUS, living with his parents and a 14year-old brother in an apartment of Buenos Aires City, Argentina. Ingestion of raw/undercooked meat, raw milk, and contact with farm animals were excluded. Virulence characteristics of the O157:H7 strain $\left(s t x_{2}, e a e, e h x \mathrm{~A}\right)$ isolated from the patient, by methods described elsewhere [11], were reported by the service Fisipopatogenia, Instituto Nacional de Enfermedades Infecciosas, ANLIS "Dr C.G. Malbrán "Buenos Aires, Argentina (2007). One dog and one cat were the companion animals of the family.

\section{Companion animals}

Both animals lived in close contact with the owners, usually climbing on the tables and beds. They were fed only with commercial food, and contact with other animals was excluded.

\section{Sample collection}

Duplicate rectal swab samples were taken weekly from the household pets at the home of a patient with HUS. The first samples were collected during the same week of HUS diagnosis (on day 4 after the HUS confirmation). Then samples were weekly collected (days 11, 18, 25, 32 and 39). Sampling was continued until two successive negative results were found for both animals.

\section{Enrichment and plating procedures}

Samples, collected in Stuart's medium, were processed the day of collection by inoculating culture tubes with tryptic soy broth (TSB) and tryptic soy broth plus tellurite and cefixime (TSB-CT). After 6 hours of incubation at $37^{\circ} \mathrm{C}$ and $42^{\circ} \mathrm{C}$ respectively in aerobiosis, cultures from TSB were streaked onto MacConkey agar (MAC), and those from TSB-CT onto sorbitol MacConkey-CT agar (SMAC-CT) plates and incubated in aerobiosis at $37^{\circ} \mathrm{C}$ for 18 hours.

\section{Screening for STEC strains by PCR assays}

E. coli strains ATCC 25922 (stx ${ }^{-}$, stx $_{2}^{-}$, eae ${ }^{-}, s_{a}{ }^{-}$, $h l y \mathrm{~A}^{-}$, and $\left.r f b \mathrm{O}_{157^{-}}\right)$, EDL 933 (O157:H7, stx ${ }^{+}$, $s t x_{2}{ }^{+}, e a e^{+}, \quad h l y \mathrm{~A}^{+}$and $\left.r f b \mathrm{O} 157^{+}\right), \quad$ UNCPBA O91:H21 (stx ${ }_{1}^{+}, s t x_{2}{ }^{+}, e a e^{-}, s a a^{+}, h l y \mathrm{~A}^{+}$and $r f b \mathrm{O} 157^{-}$ ) were used as controls. Screening for $s t x_{1}, s t x_{2}$ and $r f b_{0157}$ genes was performed by PCR as previously described [12], from the confluence zone of MAC and SMAC-CT plates as template [13]. From each positive plate at screening the presence of the genes was investigated in up to $300 \mathrm{CFU}$ through pools with up to ten colonies. Individual colonies of each positive pool were re-tested by PCR. For further identification, all positive colonies to any of the genes under study were streaked on tryptic soy agar plates.

\section{Characterization of STEC strains}

All strains were confirmed as $E$. coli by biochemical tests as previously described [13] and the enterohemolytic activity was determined using washed sheep blood cells agar supplemented with calcium according to Beutin et al. [14]. Identification of somatic (O) and flagellar $(\mathrm{H})$ antigens was performed following standard methods of tube agglutination test [15] and using currently available $\mathrm{O}(\mathrm{O} 1$ to $\mathrm{O} 181)$ and $\mathrm{H}(\mathrm{H} 1$ to $\mathrm{H} 56)$ antisera as described elsewhere [16]. Antimicrobial susceptibility patterns were determined according to CLSI standards [17], and the following antimicrobials were used: nalidixic acid, $30 \mu \mathrm{g}$; ampicillin, $10 \mu \mathrm{g} ; \quad$ ciprofloxacin, $5 \mu \mathrm{g}$; chloramphenicol, $30 \mu \mathrm{g}$; streptomycin, $10 \mu \mathrm{g}$; gentamicin, $10 \mu \mathrm{g}$, nitrofurantoin, $300 \mu \mathrm{g}$; tetracycline, $30 \mu \mathrm{g}$; and trimethoprimsulfamethoxazole, $25 \mu \mathrm{g}$. Testing conditions by disk diffusion agar and results were evaluated according to CLSI $[17,18]$. All STEC strains carrying the $s t x_{2}$ sequence were tested by PCR for the presence of eae, saa and $e h x \mathrm{~A}$ virulence genes (Table 1). Primers and PCR conditions were those described previously $[13,19,20]$. Genotyping of $s t x_{2}$ variants was performed by RFLP-PCR according to previous reports using primers VT2-c/VT2-d and VT2v1/VT2v-2 [21], VT2-e/VT2-f [22], SLTv-IIvc/CKS-2 [23] (Table 1).

\section{Results and discussion}

The first sample taken from the cat during the week of detection of the HUS case (day 4) was positive for the $s t x_{2}$ gene, but the sample collected from the dog was negative (Table 2). On days 18 and 25, samples from the dog were positive for the $s t x_{2}$ gene. On days 11, 32 and 39, samples from both animals were negative in the screening and therefore samplings were stopped. Both animals were asymptomatic during the time of sampling. The STEC strains isolated from the cat on day 4 belonged to the serotype O145:NM. The genetic profile of the 
Table 1. Primers, DNA sequences, target genes, conditions, product sizes and references of PCR used in the study

\begin{tabular}{|c|c|c|c|c|c|}
\hline Primer & Sequence $\left(5^{\prime}-3^{\prime}\right)$ & Target & Condition & Product size (bp) & Reference \\
\hline $\begin{array}{l}\text { Stx1R } \\
\text { Stx1F }\end{array}$ & $\begin{array}{l}\text { AGCGATGCAGCTATTAATAA } \\
\text { GAAGAGTCCGTGGGATTACG }\end{array}$ & $s t x_{1}$ & $\begin{array}{c}94{ }^{\circ} \mathrm{C} 30 \mathrm{~s} \\
58^{\circ} \mathrm{C} 30 \mathrm{~s} 72{ }^{\circ} \mathrm{C} 30 \mathrm{~s} \\
30 \text { cycles } \\
\end{array}$ & 130 & {$[12]$} \\
\hline $\begin{array}{l}\text { Stx2FC } \\
\text { Stx2R }\end{array}$ & $\begin{array}{l}\text { TTAACCACACCCCACCGGGCAGT } \\
\text { GCTCTGGATGCATCTCTGGT }\end{array}$ & stx $x_{2}$ & $\begin{array}{c}94^{\circ} \mathrm{C} 30 \mathrm{~s} 58^{\circ} \mathrm{C} 30 \mathrm{~s} 72^{\circ} \mathrm{C} 30 \mathrm{~s} \\
30 \text { cycles }\end{array}$ & 346 & {$[12]$} \\
\hline $\begin{array}{l}\mathrm{rfbO} 157 \mathrm{f} \\
\mathrm{rfbO} 157 \mathrm{r}\end{array}$ & $\begin{array}{l}\text { CGGACATCCATGTGATATGG } \\
\text { TTGCCTATGTACAGCTAATCC }\end{array}$ & $r f b O 157$ & $\begin{array}{c}94^{\circ} \mathrm{C} 30 \mathrm{~s} \\
58^{\circ} \mathrm{C} 30 \mathrm{~s} 72^{\circ} \mathrm{C} 30 \mathrm{~s} \\
30 \text { cycles } \\
\end{array}$ & 259 & {$[12]$} \\
\hline $\begin{array}{l}\text { eae } 1 \\
\text { eae2 }\end{array}$ & $\begin{array}{c}\text { GGAACGGCAGAGGTTAATCTGCAG } \\
\text { GGCGCTCATCATAGTCTTTC }\end{array}$ & eae & $\begin{array}{c}94{ }^{\circ} \mathrm{C} 45 \mathrm{~s} 62^{\circ} \mathrm{C} 30 \mathrm{~s} 72^{\circ} \mathrm{C} 30 \mathrm{~s} \\
30 \text { cycles }\end{array}$ & 346 & {$[13]$} \\
\hline $\begin{array}{l}\text { saaDF } \\
\text { saaDR }\end{array}$ & $\begin{array}{l}\text { CGTGATGAACAGGCTATTGC } \\
\text { ATGGACATGCCTGTGGCAAC }\end{array}$ & saa & $\begin{array}{c}95^{\circ} \mathrm{C} 1 \mathrm{~min} \\
65^{\circ} \mathrm{C} 2 \mathrm{~min}(10 \text { cycles }) \text { decrementing } \\
\text { to } 60^{\circ} \mathrm{C} 2 \mathrm{~min} \\
\text { by cycle } 15 \\
60^{\circ} \mathrm{C} 2 \mathrm{~min} \\
72^{\circ} \mathrm{C} 2.5 \mathrm{~min} \\
(10 \text { cycles }) \\
\end{array}$ & 119 & [19] \\
\hline $\begin{array}{l}\text { ehxA1 } \\
\text { ehxA2 }\end{array}$ & $\begin{array}{l}\text { GCATCATCAAGCGTACGTTCC } \\
\text { AATGAGCCAAGCTGGTTAAGCT }\end{array}$ & $e h x A$ & $\begin{array}{c}95^{\circ} \mathrm{C} 1 \mathrm{~min} \\
65^{\circ} \mathrm{C} 2 \mathrm{~min}(10 \text { cycles }) \text { decrementing } \\
\text { to } 60^{\circ} \mathrm{C} 2 \mathrm{~min} \\
\text { by cycle } 15 \\
60^{\circ} \mathrm{C} 2 \mathrm{~min} \\
72^{\circ} \mathrm{C} 2.5 \mathrm{~min} \\
(10 \text { cycles })\end{array}$ & 534 & [20] \\
\hline $\begin{array}{l}\text { VT2-c } \\
\text { VT2-d } \\
\end{array}$ & $\begin{array}{l}\text { AAGAAGATGTTTATGGCGGT } \\
\text { CACGAATCAGGTTATGCCTC }\end{array}$ & $\begin{array}{c}s t x_{2} \\
s^{\prime} x_{2(\mathrm{vh}-\mathrm{a})} \\
\text { stx }\end{array}$ & $\begin{array}{c}94{ }^{\circ} \mathrm{C} 2 \min 55^{\circ} \mathrm{C} 2 \min 72^{\circ} \mathrm{C} 1 \mathrm{~min} \\
30 \text { cycles }\end{array}$ & 285 & {$[21]$} \\
\hline $\begin{array}{l}\text { VT2v-1 } \\
\text { VT2v-2 }\end{array}$ & $\begin{array}{l}\text { CATTCAGAGTAAAAGTGGCC } \\
\text { GGGTGCCTCCCGGTGAGTTC }\end{array}$ & $\begin{array}{c}s t x_{2(\mathrm{vh}-\mathrm{a})} s t x_{2(\mathrm{vh}-\mathrm{b})} \\
s_{2} x_{2 \mathrm{~d}-\mathrm{Ount}} \\
s t x_{2 \mathrm{~d}-\mathrm{OX} 3 \mathrm{a}}\end{array}$ & $\begin{array}{c}94{ }^{\circ} \mathrm{C} 2 \min 55^{\circ} \mathrm{C} 2 \min 72^{\circ} \mathrm{C} 1 \mathrm{~min} \\
30 \text { cycles }\end{array}$ & 385 & {$[21]$} \\
\hline $\begin{array}{l}\text { VT2-e } \\
\text { VT2-f }\end{array}$ & $\begin{array}{l}\text { AATACATTATGGGAAAGTAATA } \\
\text { TAAACTGCACTTCAGCAAAT }\end{array}$ & $\begin{array}{c}s t x_{2} \\
s t x_{2(\text { vh-a) }} \text { stx } x_{2(\text { vh-b) }} \\
s t x_{2 \mathrm{~d}-O u n t} \\
s t x_{2 \mathrm{~d}-\mathrm{OX} 3 \mathrm{a}} \\
\end{array}$ & $\begin{array}{c}94{ }^{\circ} \mathrm{C} 25 \mathrm{~s} 55^{\circ} \mathrm{C} 50 \mathrm{~s} 72^{\circ} \mathrm{C} 26 \mathrm{~s} \\
30 \text { cycles }\end{array}$ & 348 & {$[22]$} \\
\hline $\begin{array}{l}\text { SLTvIIve } \\
\text { CKS2 }\end{array}$ & $\begin{array}{l}\text { ACCACTCTGCAACGTGTCGC } \\
\text { ACTGAATTGTGACACAGATTA }\end{array}$ & $\begin{array}{c}s t x_{2 \mathrm{~d}} \\
\text { activatable }\end{array}$ & $\begin{array}{l}94^{\circ} \mathrm{C} \quad 1 \mathrm{~min} \\
56^{\circ} \mathrm{C} 1 \mathrm{~min} \\
72^{\circ} \mathrm{C} \quad 1 \mathrm{~min} \\
30 \text { cycles }\end{array}$ & 890 & [23] \\
\hline
\end{tabular}


Table 2. Sampling time, screening and profile of STEC strains isolated from household pets related with a sporadic case of HUS

\begin{tabular}{|c|c|c|c|c|c|c|c|c|c|}
\hline \multirow{2}{*}{$\begin{array}{l}\text { Sampling } \\
\text { Days }\end{array}$} & \multicolumn{2}{|c|}{$\begin{array}{l}\text { Screening for } \\
\text { st } x_{1} / s t x_{2}\end{array}$} & \multirow{2}{*}{$\begin{array}{l}\text { Isolated } \\
\text { serotype }\end{array}$} & \multicolumn{5}{|c|}{ Virulence profile } & \multirow[t]{2}{*}{ stx genotype } \\
\hline & $\operatorname{dog}$ & cat & & $s t x_{1}$ & $s t x_{2}$ & eae & $e h x A$ & saa & \\
\hline 4 & - & + & O145:HNM & - & + & + & + & - & $s t x_{2}$ \\
\hline 11 & - & - & - & & & & & & \\
\hline 18 & + & - & O178:H19 & - & + & - & - & - & $s t x_{2(\mathrm{vha})}$ \\
\hline 25 & + & - & - & & & & & & \\
\hline 32 & - & - & - & & & & & & \\
\hline 39 & - & - & - & & & & & & \\
\hline
\end{tabular}

(1) Day 0: child diagnosis of HUS

isolates corresponded to $\operatorname{stx}_{2}{ }^{+} e a e^{+} e h x \mathrm{~A}^{+}$. This strain belonged to the genotype $s t x_{2}$ as determined by RFLP-PCR, and exhibited the enterohemolytic phenotype.

We were able to isolate the STEC 0178:H19 strain from the dog on day 18 . The strain carried the $s t x_{2(v h-a)}$ gene; however, it was neither enterohemolytic nor carrying eae and saa genes. Despite the positive result on screening, no STEC isolates were recovered from the sample collected from the dog on day 25. All STEC isolates were susceptible to all antibiotics tested.

In Argentina, approximately $60 \%$ of HUS cases are due to $\mathrm{O} 157: \mathrm{H7}$, and among the non-O157 STEC serotypes, O145:NM is the most frequent strain [24]. Although a high virulent O145:NM STEC serotype had been isolated from the household cat in the week of the detection of the HUS case, an O157:H7 strain was isolated from the child presenting with clinical signs of HUS.

Since screening for STEC in human samples was stopped when an STEC strain was recovered, due to the limitation of the methodology [25], one cannot exclude the possibility of isolating more than one STEC serotype from the patient with HUS and from the cat as well. In this patient case, we did not screen specifically for the O145:NM serotype. Although immunomagnetic separation-based detection of $\mathrm{O} 157$ is routinely used in human samples, IMS-based detection of serotypes other than $\mathrm{O} 157$ were not available in 2007. Moreover, IMS to O157 strains was not performed in the pets' samples.

\section{Conclusion}

A close relationship between children and their pets was seen in the city of Buenos Aires, Argentina [26]. Although it is not possible to determine the source of infection in this home, and any of the strains from the companion animals were directly associated with the sporadic case of HUS, the isolation of STEC strains in both animals from the same home is striking, especially given the local prevalence previously determined for these species which was as low as $1.1 \%(5 / 450)$ in dogs, and $2.6 \%$ (4/149) in cats [13]. Virulent STEC strains may be harboured by asymptomatic household dogs and cats, which are probably exposed to the same sources as the humans. More studies are needed to establish companion animals as a source of infection or accidental carriers of STEC in the epidemiological cycle of infections caused by STEC strains, and to develop effective control strategies for this pathogen. The isolation of O145:NM from a cat has already been documented in Germany [9]. This strain was also isolated from cattle in Argentina [27], but this is the first time that this serotype with an enterohemorrhagic E. coli virulence repertoire has been recovered from a domestic cat in our country. The potential role of dogs and cats in the epidemiological cycle of STEC human infection is still poorly investigated. Due to the close cohabitation between companion animals and their owners, the transmission of sporadic cases of HUS is probable.

\section{Acknowledgements}

The authors wish to thank $\mathrm{PhD}$. O. Degregorio, for helpful technical assistance, $\mathrm{PhD}$. N. Padola for kindly providing the UNCPBA O91:H21 strain, and Dr. A. Leyva for English editing of the manuscript. 
The study was financially supported by the following grants: Carrillo-Oñativia, National Commission Health Research, National Ministry of Health, Argentine; UBACyT 20020100100882 and PIRIVE 97-22 ICyTDF, México.

\section{References}

1. Ministerio de Salud de la Nación Argentina 2009, http://www.msal.gov.ar/htm/Site/sala_situacion/PANELES/ Problemas\%20emergentes/Nacional/SUH.gif.

2. Exeni RA (1996) Síndrome urémico hemolítico. Medicina (Buenos Aires) 56:197-198.

3. Mead PS, Griffin PM (1998) Escherichia coli O157:H7. Lancet 352: 1207-1212.

4. Rivas M, Sosa-Estani S, Rangel J, Caletti MG, Vallés P, Roldán CD, Balbi L, Marsano de Mollar MC, Amoedo D, Miliwebsky E, Chinen I, Hoekstra RM, Mead P, Griffin PM (2008) Risk factors for sporadic Shiga toxin-producing Escherichia coli infections in children, Argentina. Emerg Infect Dis 14: 763-771.

5. Meichtri L, Gioffré A, Miliwebsky E, Chinen I, Chillemi G, Masana M, Cataldi A, Rodríguez H, Rivas M (2004) Prevalence and characterization of shiga toxin producing Escherichia coli in beef cattle from Argentina. Int J Food Microbiol 96: 189-198.

6. Rangel JM, Sparling PH, Crowe C, Griffin PM, Swerdlow DL (2005) Epidemiology of Escherichia coli O157:H7 outbreaks, United States, 1982-2002. Emerg Infect Dis. 11: 603-609.

7. Parma AE, Sanz ME, Blanco JE, Blanco J, Viñas MR, Blanco M, Padola NL Etcheverría AI (2000) Virulence genotypes and serotypes of verotoxigenic E. coli isolated from cattle and foods in Argentina. Importance in public health. Eur J Epidemiol 16: 757-762.

8. Beutin L, Geier D, Steinruck H, Zimmermann S, Scheutz F (1993) Prevalence and some properties of verotoxin (Shigalike toxin)-producing Escherichia coli in seven different species of healthy domestic animals. J Clin Microbiol 31: 2483-2488.

9. Busch U, Hörmansdorfer S, Schranner S, Huber I, Bogner KH, Sing A (2007) Enterohemorrhagic Escherichia coli excretion by child and her cat. Emerg Infect Dis 13: 348349.

10. Kataoka Y, Irie, Y, Sawada, T, Nakazawa, M (2010) A 3year epidemiological surveillance of Escherichia coli O157:H7 in dogs and cats in Japan. J Vet Med Sci 72: 791794.

11. Rivas M, Miliwebsky E, Deza N (2007) Manual de procedimientos, Diagnóstico y caracterización de Escherichia coli $\mathrm{O} 157$ productor de toxina Shiga a partir de especímenes clínicos. http://fos.panalimentos.org/gfn/ManualesdeProcedimiento/ta bid/783/language/es-ES/Default.aspx.

12. Leotta GA, Chinen I, Epszteyn S, Miliwebsky E, Melamed IC, Motter M, Ferrer M, Marey E, Rivas M (2005) Validación de una técnica de PCR múltiple para la detección de Escherichia coli productor de toxina Shiga. Rev Argent Microbiol 37: 1-10.

13. Bentancor A, Rumi MV , Gentilini MV, Sardoy C, Irino K, Agostini A, Cataldi A (2007) Shiga toxin-producing and attaching and effacing Escherichia coli in cats and dogs in a high Hemolytic Uremic Syndrome incidence region in Argentina. FEMS Microbiol Lett 267: 251-256.
14 Beutin L, Montenegro MA, Orskov I, Orskov F, Prada J, Zimmermann S, Stephan R (1989) Close association of verotoxin (Shiga-like toxin) production with enterohemolysin production in strains of Escherichia coli. J Clin Microbiol 27: 2559-2564.

15 Ewing WH, Edwards PR (1986) Edwards and Ewing's Identification of Enterobacteriaceae, 4th edition. New York: Elsevier Science Publishers. 1262 p.

16 Vaz TMI, Irino K, Kato MAMF, Dias AMG, Gomes TAT, Medeiros MIC, Rocha MM, Guth BEC (2004) Virulence properties and characteristics of Shiga toxin-producing Escherichia coli in São Paulo, from 1976 through 1999. J Clin Microbiol 42: 903-905.

17. CLSI (2009) Performance Standards for Antimicrobial Disk Susceptibility Test; Approved Standard," Tenth Edition, CLSI document M02-A10. Wayne, Pennsylvania, USA.

18. CLSI (2009) Performance Standards for Antimicrobial Susceptibility Testing, Nineteenth Informational Supplement. CLSI document M100-S19. Wayne, Pennsylvania, USA.

19. Paton AW and Paton JC (2002) Direct detection and characterization of Shiga toxigenic Escherichia coli by multiplex PCR for stx $1, s t x 2$, eae, ehx A, and saa. J Clin Microbiol 40: 271-274.

20. Paton AW and Paton JC (1998) Detection and characterization of Shiga toxigenic $E$. coli by using multiplex PCR assays for stx 1, stx2, eaeA, enterohemorrhagic E. coli hlyA, rfbO111, and rfbO157. J Clin Microbiol 36: 598-602.

21. Tyler SD, Johnson WM, Lior H, Wang G, Rozee KR (1991) Identification of verotoxin type 2 variant B subunit genes in Escherichia coli by the polymerase chain reaction and restriction fragment length polymorphism analysis. J Clin Microbiol 29: 1339-1343.

22. Piérard D, Muyldermans G, Moriau L, Stevens D, Lauwers S (1998) Identification of new verocytotoxin type 2 variant B subunit genes in human Escherichia coli isolates. J Clin Microbiol 36: 3317-3322.

23. Jelacic JK, Damrow T, Chen GS, Jelacic S, Bielaszewska M, Ciol M, Carvalho HM, Melton-Celsa AR, O'Brien AD, Tarr PI (2003) Shiga toxin-producing Escherichia coli in Montana: bacterial genotypes and clinical profiles. J Infect Dis 188: 719-29.

24. Miliwebsky E, Deza N, Chinen I, Martinez Espinosa E, Gomez D, Pedroni E, Caprile L, Bashckier A, Manfredi E, Leotta G, Rivas M (2007) Prolonged fecal shedding of Shiga toxin-producing Escherichia coli among children attending day-care centers in Argentina. Rev Argent Microbiol 39: 9092.

25. Cohen NJ, Jones RC, Schermond JS, Gerber SI (2008) Identifying Shiga Toxin-producing Escherichia coli: Results of a Laboratory Evaluation. Foodborne Pathog Dis 5: 295301.

26. Sommerfelt I and Franco A (2001) Relaciones entre el hombre y los animales de compañía. Rev Med Vet 83: 181184.

27. Padola NL, Sanz ME, Lucchesi MA, Blanco JE, Blanco J, Blanco M, Etcheverría AI, Arroyo GH, Parma AE (2002) First isolation of the enterohaemorrhagic Escherichia coli O145:HNM from cattle in feedlot in Argentina. BMC Microbiol 2: 6. 


\section{Corresponding author}

Adriana B. Bentancor

Facultad de Ciencias Veterinarias

Universidad de Buenos Aires

Chorroarín 280

Ciudad Autónoma de Buenos Aires, Argentina

Telephone: +54-11-4524-8421

Email: aben@fvet.uba.ar

Conflict of interests: No conflict of interests is declared 